Bull. Chem. Soc. Ethiop. 2014, 28(2), 177-185.

Printed in Ethiopia

ISSN 1011-3924

DOI: http://dx.doi.org/10.4314/bcse.v28i2.2

(c) 2014 Chemical Society of Ethiopia

\title{
ASSESSMENT OF MACRONUTRIENTS AND HEAVY METALS IN FAGONIA CRETICA LINN OF PAKISTAN BY ATOMIC SPECTROSCOPY
}

\author{
Kashif Naeem*, Wasim Yawar, Bashir Muhammad and Ishrat Rehana \\ Central Analytical Facility Division, Pakistan Institute of Nuclear Science and Technology, P.O. \\ Nilore, Islamabad 45650, Pakistan
}

(Received July 18, 2013; revised April 2, 2014)

\begin{abstract}
The macronutrients and heavy metals content of different parts of a locally found herb named Fagonia cretica, an important medicinal herb, were investigated. $\mathrm{Al}, \mathrm{Ca}, \mathrm{Co}, \mathrm{Cr}, \mathrm{Cu}, \mathrm{Fe}, \mathrm{K}, \mathrm{Mg}, \mathrm{Mn}, \mathrm{Na}, \mathrm{Sr}$ and $\mathrm{Zn}$ were measured in roots, shoots, leaves, spines and flowers/fruits of the plant. The analysis was carried out by inductively coupled plasma optical emission spectrometry (ICP-OES) and atomic absorption spectrophotometry (AAS). The results revealed that the Fagonia cretica accumulate the elemental contents at different parts. The accuracy of the method was checked by analysing a certified reference material and the results were in agreement with the enumerate value. The presence of a certain set of elements at percentage level like $\mathrm{Ca}, \mathrm{K}$ and $\mathrm{Mg}$ is useful for strengthening of bones and body. Other elements important from health perspective including $\mathrm{Al}, \mathrm{Co}$, $\mathrm{Cr}, \mathrm{Cu}, \mathrm{Fe}, \mathrm{Mn}, \mathrm{Na}, \mathrm{Sr}$ and $\mathrm{Zn}$ are found at ppm levels in all parts of the plant.
\end{abstract}

KEY WORDS: Fagonia cretica, Macronutrients, Heavy metals, ICP-OES, AAS

\section{INTRODUCTION}

The subject of medicinal plants has been gaining interest and recognition worldwide [1-3]. According to WHO survey about $80 \%$ of world's population used herbal medicines for treatment of various diseases [4]. The herbal medicines are also being used as sources of minerals, indispensable for proper functioning of human organs [5]. The role of trace metals in human health and diseases is well established for calcium metabolism, brain function, energy metabolism, potentiating insulin action in the metabolism of glucose and lipids on diabetes resulting from inadequate synthesis of insulin, and perhaps immune process [6]. Active ingredients from plants/herbs individually or in combination from different sources are generating new interest in modern drug therapies. The concurrent use of herbs may mimic, magnify, or oppose the effect of drugs [7]. Combined with lifestyle changes; herbal therapies offer a vastly safer and similarly effective remedy for menopausal symptoms. Same herbs may also decrease the risk of heart disease, breast cancer and osteoporosis [8]. The safety of plants and their infusions used as herbal medicines needs to be ensured, i.e. the freedom from toxic metals, which otherwise may be considered as cause of heavy metal intoxication thus making their medicinal use questionable [9].

The herb Fagonia cretica belonging to the family Zygophyllaceae has palmate compound leaves, stiff stipules and purple flowers. It is found on dry calcareous rocks throughout the world including Pakistan [10]. In Pakistan, it is commonly called dhamasa, widely used for the treatment of various diseases like other parts of world since it possesses antibacterial properties against pathogenic microorganisms. It is being used for the treatment of fever, asthma, thirst, vomiting, typhoid, stomach trouble, urinary discharge, tooth ache, skin diseases prophylactic against small pox, blood purification and also considered to be remedial for cancer $[10,11]$. The herb is also used in many ways like paste of the whole plant can be applied to tumors and scrofulous swellings [12]. Its leaves and twigs are used for snakebite [13] whereas the boiled residue of the herb is used to induce abortion [10].

*Corresponding author. E-mail: naeemkashif@yahoo.com 
Plants and especially medicinal plants deserve special attention because of their beneficial therapeutic properties. The dietary supplements of macronutrients and trace heavy metals from herbs and their products play both curative and preventive role in combating diseases. The macronutrients occur as a group in foods rather than singly, widespread deficiencies of these may occur due to food processing. Due to their potential effects on human health, accurate quantitative analysis of the elemental content of plants is very important.

In the past, many spectroscopic techniques have been used to determine toxic and essential elements in various matrices. However, inductively coupled plasma-optical emission spectrometry (ICP-OES) [14, 15], flame atomic absorption spectrometry (FAAS) [14, 16-19] and inductively coupled plasma-mass spectrometry (ICP-MS) [20] have been the most effectively used techniques for the determination of heavy metals in biological materials and pharmaceutical products. Graphite furnace atomic absorption spectrometry (GFAAS) is now frequently used for trace metal analysis in biological, clinical, environmental, food, geological and many other materials [21-23]. This study was aimed at presenting the macronutrients and trace heavy metals of a medicinal herb named $F$. cretica Linn. and level of toxic metals by inductively coupled plasma-optical emission spectrometry and atomic absorption spectrometry. Their levels could be beneficial to the pharmacological industry for assessing its medicinal and nutritional values, and also to ascertain its safety from toxic metals.

\section{EXPERIMENTAL}

\section{Reagents}

The reagents used for the dissolution of samples, such as nitric acid, hydrogen peroxide and sulfuric acid were analytical reagent grade obtained from E. Merck, Germany. Deionized distilled water was used throughout this work. Five multielement calibration standards containing $0.1,1,5,50$ and $100 \mu \mathrm{gL}^{-1}$ of $\mathrm{Al}, \mathrm{Ca}, \mathrm{Cd}, \mathrm{Co}, \mathrm{Cr}, \mathrm{Cu}, \mathrm{Fe}, \mathrm{K}, \mathrm{Mg}, \mathrm{Mn}, \mathrm{Na}, \mathrm{Ni}, \mathrm{Pb}$, $\mathrm{Sr}$ and $\mathrm{Zn}$ were prepared by serial dilution from the Specpure grade Multielement Plasma Standard Solution 4 (Alpha Aesar, USA), which contains $1000 \mu \mathrm{g} \mathrm{mL} \mathrm{mL}^{-1}$ each of the above elements. Stock solutions, $1000 \mathrm{mg} \mathrm{L}^{-1}$ of each of $\mathrm{Cu}, \mathrm{Fe}$ and $\mathrm{Zn}$ were prepared for AAS analysis with Specpure Johnson Matthey Chemicals. Calibration standards for AAS were prepared using their stock solutions by employing serial dilution technique. Working standard solutions were prepared by dilution just before the analysis with deionized distilled water. Glassware was cleaned by overnight soaking in $\mathrm{HNO}_{3}(1+9)$ followed by repeated rinsing with deionized distilled water.

\section{Sampling}

The herb, F. cretica, was randomly collected from Kohat district of Pakistan. The herb was washed thoroughly with running tap water and then washed with deionized distilled water to remove superficial soil particles. The collected herb was dried in open at room temperature. Different parts of herb including leaves, stems, roots, spines and flowers/fruits were separated using steel plant cutter. These individual parts, $100 \mathrm{~g}$ each, were ground using a tungsten ball mill and sieved through $100 \mu$ mesh size sieve. The samples were thoroughly mixed and homogenized by the coning and quartering technique. The homogenized samples were stored in plastic bags inside the desiccators to protect them from humidity before acid digestion. 


\section{Dissolution}

Microwave digestion system, Aurora500 (Aurora Inc. Canada) was used for dissolution of samples. Very High Pressure (VHP) Teflon sample vessels were used in this system which can sustain temperature up to $230{ }^{\circ} \mathrm{C}$ and pressure up to $625 \mathrm{psi}$. An amount of $0.5 \mathrm{~g}$ of powdered sample was taken in a VHP digestion vessel of the microwave digestion system, to which $5 \mathrm{~mL}$ of concentrated $\mathrm{HNO}_{3}, 1 \mathrm{~mL}$ of $\mathrm{H}_{2} \mathrm{O}_{2}$ and $1 \mathrm{~mL}$ of $\mathrm{H}_{2} \mathrm{SO}_{4}$ were added. The vessel was properly sealed and placed in the microwave oven. The microwave heating program used in this work is given in Table 1. After cooling the samples were transferred to $25 \mathrm{~mL}$ volumetric flasks and made up the volume to the mark with deionized water. A blank was prepared using the same microwave procedure given above excluding the sample.

Table 1. Digestion program for F. cretica using Aurora500 Microwave Oven.

\begin{tabular}{|c|c|c|c|}
\hline Step & Temperature target $\left({ }^{\circ} \mathrm{C}\right)$ & Ramp time (min:sec) & Dwell Time (min:sec) \\
\hline 0 & 25 & 0 & 0 \\
\hline 1 & 130 & $3: 00$ & 0 \\
\hline 2 & 175 & $2: 30$ & 0 \\
\hline 3 & 180 & $4: 30$ & $5: 0$ \\
\hline
\end{tabular}

\section{Instrumentation}

Metal analysis was carried out using ICP-OES spectrometer iCAP 6500 (Thermo Fisher, UK) equipped with an echelle polychromator having charge injection device detector enabling all wavelengths to be measured simultaneously. The operating conditions were as follows: viewing height $15 \mathrm{~mm}$ radial, nebulizer gas flow rate $0.7 \mathrm{~L} \mathrm{~min}^{-1}$, auxiliary gas flow rate $0.5 \mathrm{~L} \mathrm{~min}^{-1}$, coolant gas flow rate $12 \mathrm{~L} \mathrm{~min}^{-1}$, flush pump rate $100 \mathrm{rpm}$, analysis pump rate $50 \mathrm{rpm}$ and pump stabilization time $5 \mathrm{~s}$. The wavelength (nm) used were $\mathrm{Al}$ 396.152, Ca 393.336, Co 228.62, Cr 205.55, Cu 324.75, Fe 259.94, K 766.490, Mg 279.553, Mn 257.61, Na 589.592, Sr 407.771 and 421.552, and Zn 213.856. Atomic absorption spectrometer Z-8000 (Hitachi, Japan) equipped with Zeeman background correction was used for the proportional measurements of $\mathrm{Cu}, \mathrm{Fe}$ and $\mathrm{Zn}$. Hollow cathode lamps of $\mathrm{Cu}, \mathrm{Fe}$ and $\mathrm{Zn}$ were used as radiation sources. The operating parameters for working elements were adjusted according to the manufacturer's recommendation. Measurements were carried out in an air-acetylene flame. The element $\mathrm{Cu}$ was determined using graphite furnace atomic absorption spectrometry. Argon gas at flow rate of $100 \mathrm{~mL} \mathrm{~min}^{-1}$ was used as inert gas and its flow was interrupted during the atomization step.

\section{Procedure}

The ICP-OES was calibrated using the calibration standards mentioned above (reagent section). Both the samples and blank were then analyzed by ICP-OES. Blank and background correction were applied. The lines chosen for different elements have no spectral interferences for the major components of the samples. For FAAS measurement the absorbance value of standards, blank and sample was measured by aspirating the solutions into the nebulizer of atomic absorption spectrophotometer. The absorbance of $\mathrm{Cu}$ standards, blank and sample was measured by injecting $10 \mu \mathrm{L}$ solution into cold graphite tube of graphite atomizer. The graphite furnace program is as follows: dry at $80-120{ }^{\circ} \mathrm{C}$ for $60 \mathrm{~s}$, char the sample at $600{ }^{\circ} \mathrm{C}$ for $30 \mathrm{~s}$, atomize at $2900{ }^{\circ} \mathrm{C}$ and cleaning at $3000{ }^{\circ} \mathrm{C}$ for $3 \mathrm{~s}$. A minimum of three absorbance values were recorded and average of absorbance values was used for calculation. 
Quality control studies

Accuracy of the data was checked by a similar analysis of two standard reference materials. The standard reference materials, SRM-1547, (Peach leaves) and BCR-189 (Whole meal flour) were digested simultaneously with the herb samples and analyzed by ICP-OES and AAS, respectively.

\section{RESULTS AND DISCUSSION}

Fifteen elements namely $\mathrm{Al}, \mathrm{Ca}, \mathrm{Cd}, \mathrm{Co}, \mathrm{Cr}, \mathrm{Cu}, \mathrm{Fe}, \mathrm{K}, \mathrm{Mg}, \mathrm{Mn}, \mathrm{Na}, \mathrm{Ni}, \mathrm{Pb}, \mathrm{Sr}$ and $\mathrm{Zn}$ were determined in different parts of Fagonia cretica Linn. by ICP-OES and AAS owing to therapies evolved around the implementation of diet and the elements of nutrition to address health problems. Table 2 lists the concentrations of major-to-trace elements determined by ICP-OES along with standard deviation (SD). The elements results show that this herb contains a lot of elements of vital importance in human being's metabolism and that they are needed for growth, development, prevention and treatment of many diseases. The ranges of elemental concentrations have been found to vary widely between $6.0 \pm 0.6 \mu \mathrm{g} / \mathrm{g}$ to $57845 \pm 165 \mu \mathrm{g} / \mathrm{g}$ in different parts of $F$. cretica. It is evident from data in Table 2 that different parts of $F$. cretica are good sources of the essential elements especially $\mathrm{Ca}, \mathrm{K}$ and $\mathrm{Mg}$ which are present at percentage level, $F$. cretica can provide significant amounts of these elements to the body. Deficiency of all three of them can derange the metabolism. Among all the detected elements $\mathrm{Ca}$ has the maximum concentration of $57845 \mu \mathrm{g} / \mathrm{g}$ in leaves. It is present in the range of 1208 $57845 \mu \mathrm{g} / \mathrm{g}$ with the lowest value in stem and highest value is in leaves. The high values of $\mathrm{Ca}$ are attributed to its involvement in bones and teeth formation, prevention of osteoporosis, muscular contraction, regulation of heart beat and cellular permeability [24, 25]. According to Shills and Yong [26] that good food Ca content is greater than $1 \mathrm{mg} / 100 \mathrm{~g}$ and poor if less than $0.5 \mathrm{mg} / 100 \mathrm{~g}$. From the result, the investigated herb was rated a good source of $\mathrm{Ca}$ food. $\mathrm{K}$ is present at high concentration level ranging between 1024-10642 $\mu \mathrm{g} / \mathrm{g}$ with lowest value in flower/fruit and highest value in stems. $\mathrm{K}$ is necessary in reducing hypertension, for muscle contraction (especially cardiac fibre) and for the synthesis of some proteins and as an enzymic cofactor [25]. In the human body, this element play vital role in many physiological reactions and their deficiency or excess can affect human health. $\mathrm{Mg}$ is present at high concentration level ranging between 590-2217 $\mu \mathrm{g} / \mathrm{g}$ with lowest value in roots and highest value in leaves. $\mathrm{Mg}$ is important for any biochemical process in an organism, promotes balancing of minerals, and it is necessary for normal job of muscles, and nervous system [27], activity of hormones, manufacture of energy maintenance of health of reproductive system, immune system and regulation of an intimate rhythm and arterial pressure together with $\mathrm{Ca}$ [28].

The heavy metals $\mathrm{Co}, \mathrm{Cr}, \mathrm{Fe}, \mathrm{Mn}, \mathrm{Na}, \mathrm{Sr}$ and $\mathrm{Zn}$, present at $\mathrm{ppm}$ or $\mu \mathrm{g} / \mathrm{g}$ level, were determined. They play both curative and preventive role in combating diseases. Co is present at ppm level ranging between 20-599 $\mu \mathrm{g} / \mathrm{g}$ with lowest value in leaves and highest in the spines. Co promotes $\mathrm{RBC}$ formation, activates enzymes and replaces $\mathrm{Zn}$ in some enzymes. It is involved in the formation of vitamin $\mathrm{B}_{12}$ or cobalamin and as such essential for erythrocyte formation and the maintenance of nerve tissue [29]. $\mathrm{Cr}$ is present at ppm level ranging between 6-13 $\mu \mathrm{g} / \mathrm{g}$ with lowest value in flowers/fruits and highest value in stems while it is absent in leaves. $\mathrm{Cr}$ is an essential element required for carbohydrate, lipid, protein, nucleic acid metabolisms and maintenance of normal glucose tolerance by increasing insulin activity in animals and humans [30]. $\mathrm{Cu}$ is present at ppm level ranging between 13-29 $\mu \mathrm{g} / \mathrm{g}$. The lowest values are reported in roots and flowers/fruits while highest value is found in the leaves. The amount present is below the detection limits in stems and spines. $\mathrm{Cu}$ is a part of many enzymes playing very important role in the functioning of human body. An excess or deficiency of $\mathrm{Cu}$ is illustrated by several copper-associated disorders in man, such as Menkes and Wilson disease

Bull. Chem. Soc. Ethiop. 2014, 28(2) 
[31] and might also be related to the pathophysiology of schizophrenia [32]. Fe is also present at ppm level ranging between $129-834 \mu \mathrm{g} / \mathrm{g}$ with lowest value in leaves and highest value in roots. Fe improves the function of enzymes in protein metabolism and enhances the functions of $\mathrm{Ca}$ and $\mathrm{Cu}$. It plays an important role in the production of hemoglobin and is responsible for oxygen transport in human body [33]. Mn is present at ppm level ranging between 11-36 $\mu \mathrm{g} / \mathrm{g}$, lowest value in roots and highest value in leaves. Mn serve as cofactor in many enzyme systems including those involved in bone formation, energy production, and metabolism of protein, carbohydrate and fat. It enhances smooth muscle relaxation and promotes normal growth, development and cell function [28]. $\mathrm{Na}$ is present at ppm level ranging between 79-272 $\mu \mathrm{g} / \mathrm{g}$ showing lowest value in stems and highest value in roots. $\mathrm{Na}$ is necessary for human body to maintain water balance and blood $\mathrm{pH}$, transition of fluids across cell membranes, digestion, nerve function and muscle contractions. Na works in conjunction with $\mathrm{K}$ for extracellular fluid balances [27]. In addition to the important individual role of $\mathrm{K}$ and $\mathrm{Na}$ in human physiology, interesting correlation has been established between $\mathrm{K} / \mathrm{Na}$ ratios and a diet with high $\mathrm{K}$ and low $\mathrm{Na}$ concentrations can lower blood pressure [34]. It is noticeable that the $\mathrm{K}$ to $\mathrm{Na}$ ratio ranges of 26.5 in roots, 135 in stems, 22.3 in leaves, 34.4 in spines and 10.4 in flowers/fruits ensure that the use of this herb for the treatment of high blood pressure is justifiable. $\mathrm{Sr}$ is present at ppm level ranging between $24-325 \mu \mathrm{g} / \mathrm{g}$ having lowest value in roots and highest vale in leaves. $\mathrm{Sr}$ ranelate decrease bone resorption and maintains a high bone formation and helps to prevent teeth and bone loss [35]. $\mathrm{Zn}$ is present at ppm level ranging between 12-139 $\mu \mathrm{g} / \mathrm{g}$ with lowest value present in spines and highest value in leaves. $\mathrm{Zn}$ is very important nutrient involved in glucose and lipid metabolism, hormone function and healing ability of body, and is also associated with proper hair growth [36]. Its deficiency in the organism is accompanies by multisystem dysfunction [37].

The toxic metals $\mathrm{Cd}, \mathrm{Pb}$ and $\mathrm{Ni}$ were altogether absent and the absence of the toxic heavy metals in all parts of the samples indicates that the collected herbs were unpolluted in their natural habitats and were grown in a clean environment. The safety, effectiveness and good quality of medicinal herb has been established by the present study. Similarly, the safety, effectiveness and quality of finished medicinal products depend on the quality of the source materials and it is evident that medicine prepared from $F$. cretica grown in Kohat district and all such clean environments will be safe and not contain toxic metals from source material.

Table 2. Concentration of macronutrients and heavy metals (mean \pm SD in $\mu \mathrm{g} / \mathrm{g}$ ) in various parts of $F$. cretica.

\begin{tabular}{|l|l|l|l|l|l|}
\hline Elements & Roots & Stems & Leaves & Spines & Flowers/fruit \\
\hline $\mathrm{Al}$ & $335 \pm 20$ & $263 \pm 9$ & $1344 \pm 33$ & $171 \pm 6$ & $1016 \pm 41$ \\
\hline $\mathrm{Ca}$ & $2740 \pm 84$ & $1208 \pm 184$ & $57845 \pm 165$ & $17861 \pm 138$ & $12736 \pm 635$ \\
\hline $\mathrm{Co}$ & $80.0 \pm 2.5$ & $21.0 \pm 1.5$ & $20.0 \pm 1.0$ & $599 \pm 31$ & $49.0 \pm 2.5$ \\
\hline $\mathrm{Cr}$ & $9.0 \pm 0.2$ & $13.0 \pm 1.0$ & $<2.1$ & $9.0 \pm 0.6$ & $6.0 \pm 0.6$ \\
\hline $\mathrm{Cu}$ & $13.0 \pm 0.3$ & $<3.5$ & $29.0 \pm 1.5$ & $<3.5$ & $13.0 \pm 0.6$ \\
\hline $\mathrm{Fe}$ & $834 \pm 23$ & $167 \pm 2$ & $129 \pm 2$ & $171 \pm 2$ & $293 \pm 1$ \\
\hline $\mathrm{K}$ & $7204 \pm 192$ & $10642 \pm 99$ & $4992 \pm 96$ & $3512 \pm 61$ & $1024 \pm 29$ \\
\hline $\mathrm{Mg}$ & $590 \pm 42$ & $1357 \pm 8$ & $2217 \pm 204$ & $1165 \pm 59$ & $1201 \pm 29$ \\
\hline $\mathrm{Mn}$ & $11.0 \pm 0.3$ & $15.0 \pm 1.0$ & $36.0 \pm 2.0$ & $16.0 \pm 0.6$ & $17.0 \pm 1.0$ \\
\hline $\mathrm{Na}$ & $272 \pm 24$ & $79.0 \pm 2.0$ & $224 \pm 4$ & $102 \pm 3$ & $98.0 \pm 2.0$ \\
\hline $\mathrm{Sr}$ & $24.0 \pm 0.8$ & $63.0 \pm 0.6$ & $325 \pm 5$ & $80.0 \pm 2.5$ & $81.0 \pm 2.5$ \\
\hline $\mathrm{Zn}$ & $13.0 \pm 0.2$ & $36.0 \pm 2.5$ & $139 \pm 8$ & $12.0 \pm 1.0$ & $82.0 \pm 3.5$ \\
\hline
\end{tabular}


As it can be noticed from the elemental data in Table 2, $\mathrm{Al}$ is present at ppm level ranging between 171-1344 $\mu \mathrm{g} / \mathrm{g}$ with lowest value in spines and highest value in leaves. Role of $\mathrm{Al}$ as an antacid is well documented [38], although it is also toxic in inorganic form and limits of intake are defined. The elemental results of different parts of $F$. cretica show that most of the parts contain elements of vital importance in man's metabolism and that are needed for growth, development, prevention and treatment of many diseases. It is evident that they are important sources of essential mineral elements in reasonable concentrations which are required in the treatment of many diseases. Part of an herb's healing effect is due to the synergy or sum total of all the constituents.

On the basis of the results obtained in the present work, it is concluded that the techniques are established as suitable for the routine determination of essential and toxic metals in various pharmaceutical dosage forms. ICP-OES is rapid regarding simultaneous determination of these elements. The employment of proper microwave digestion system provided a better effective method of sample preparation and facilitated the analysis in terms of speed. The losses of volatile elements were also avoided due to the digestion in a closed system with good temperature control. Table 3 demonstrates the elemental concentrations of $\mathrm{Fe}, \mathrm{Cu}$ and $\mathrm{Zn}$ obtained by both ICP-OES and AAS after the microwave digestion applied to different parts of $F$. cretica Linn. It shows that the data is in accordance with both the techniques. There is a vast scope to exploit the preventive medicinal aspects of various trace metals as the requirements vary according to the levels of essential and toxic elements generate systematic data which may be used as control therapy for various diseases.

Table 3. Concentration $(\mu \mathrm{g} / \mathrm{g})$ of $\mathrm{Cu}, \mathrm{Fe}$ and $\mathrm{Zn}$ by ICP-OES and AAS after the microwave digestion of different parts of $F$. cretica.

\begin{tabular}{|l|l|l|l|l|l|l|}
\hline Element & Technique & Roots & Stems & Leaves & Spines & Flowers/fruit \\
\hline $\mathrm{Cu}$ & ICP-OES & $13.0 \pm 0.3$ & $<3.5$ & $29.0 \pm 1.5$ & $<3.5$ & $13.0 \pm 0.6$ \\
\cline { 2 - 7 } & AAS & $14.0 \pm 0.4$ & $8.3 \pm 0.8$ & $30.3 \pm 1.9$ & $5.2 \pm 0.3$ & $14.0 \pm 0.9$ \\
\hline \multirow{2}{*}{$\mathrm{Fe}$} & ICP-OES & $834 \pm 23$ & $167 \pm 2$ & $129 \pm 2$ & $171 \pm 2$ & $293 \pm 1$ \\
\cline { 2 - 7 } & AAS & $841 \pm 20$ & $120 \pm 5$ & $118 \pm 4$ & $157 \pm 4$ & $263 \pm 6$ \\
\hline $\mathrm{Zn}$ & ICP-OES & $13.0 \pm 1.1$ & $36.0 \pm 2.5$ & $139 \pm 7$ & $12.0 \pm 1.0$ & $82.0 \pm 3.5$ \\
\cline { 2 - 7 } & AAS & $12.9 \pm 0.9$ & $30.4 \pm 0.5$ & $167 \pm 7$ & $10.2 \pm 0.5$ & $86.8 \pm 5.0$ \\
\hline
\end{tabular}

Table 4. Comparison of the measured values with certified values (mean $\pm \mathrm{SD}$ in $\mu \mathrm{g} / \mathrm{g}$ ) of standard reference material, SRM-1547 (Peach leaves).

\begin{tabular}{|l|l|l|}
\hline Elements & Measured value & Certified value \\
\hline $\mathrm{Al}$ & $235 \pm 5$ & $249 \pm 8$ \\
\hline $\mathrm{Ba}$ & $118 \pm 1$ & $124 \pm 4$ \\
\hline $\mathrm{Ca}$ & $15100 \pm 240$ & $15600 \pm 200$ \\
\hline $\mathrm{Cd}$ & $<0.5$ & $0.026 \pm 0.003$ \\
\hline $\mathrm{Co}$ & $0.08 \pm 0.05$ & 0.07 \\
\hline $\mathrm{Fe}$ & $208 \pm 3$ & $218 \pm 14$ \\
\hline $\mathrm{K}$ & $23900 \pm 460$ & $24300 \pm 300$ \\
\hline $\mathrm{Mg}$ & $4230 \pm 66$ & $4320 \pm 80$ \\
\hline $\mathrm{Mn}$ & $92 \pm 1$ & $98 \pm 3$ \\
\hline $\mathrm{Na}$ & $29 \pm 2$ & $24 \pm 2$ \\
\hline $\mathrm{Pb}$ & $0.87 \pm 0.06$ & $0.87 \pm 0.03$ \\
\hline $\mathrm{Sr}$ & $54 \pm 1$ & $53 \pm 4$ \\
\hline $\mathrm{Zn}$ & $21.0 \pm 0.1$ & $17.9 \pm 0.4$ \\
\hline
\end{tabular}


To check the validity and authenticity of the method and generated data, quality control measures were adopted. The analytical procedures were confirmed by analysis of standard reference materials (SRMs) and recovery checks. It is apparent from the elemental data in Tables 4 and 5 that the method is accurate and can be successfully applied for obtaining reliable elemental concentrations and ensuring the quality and safety of herbal plants and their medicinal products. On comparing the concentration values of the elements obtained with the certified ones, the measured values of the elements were found to be in good agreement with the certified values. The precision obtained with the digestion procedure for the SRM was considered good.

Table 5. Comparison of the measured values with certified values (mean $\pm \mathrm{SD}$ in $\mu \mathrm{g} / \mathrm{g}$ ) of standard reference material, BCR-189, Whole meal flour.

\begin{tabular}{|l|l|l|}
\hline Elements & Measured value & Certified value \\
\hline $\mathrm{Cu}$ & $6.1 \pm 0.3$ & $6.4 \pm 0.2$ \\
\hline $\mathrm{Fe}$ & $69.6 \pm 1.8$ & $68.3 \pm 1.9$ \\
\hline $\mathrm{Zn}$ & $61.1 \pm 0.4$ & $56.5 \pm 1.7$ \\
\hline
\end{tabular}

The accuracy of method was confirmed by conducting percentage recovery studies. Known quantities of $\mathrm{Fe}, \mathrm{Cu}, \mathrm{Mn}$ and $\mathrm{Zn}$ were added directly to some of the digested sample solutions. The results, presented in Table 6 , show that the recoveries of spiked samples were satisfactorily reasonable for analysis, in a range of $94-102 \%$.

Table 6. Results of recovery assays for $\mathrm{Cu}, \mathrm{Fe}, \mathrm{Mn}$ and $\mathrm{Zn}$.

\begin{tabular}{|l|l|l|l|}
\hline Elements & Amount added & Amount recovered & $\%$ recovery \\
\hline \multirow{5}{*}{$\mathrm{Cu}(\mathrm{ng} / \mathrm{g})$} & 0 & $162 \pm 4$ & - \\
\cline { 2 - 4 } & 50.0 & $211 \pm 5$ & 98 \\
\cline { 2 - 4 } & 100.0 & $264 \pm 7$ & 102 \\
\hline \multirow{3}{*}{$\mathrm{Fe}(\mu \mathrm{g} / \mathrm{g})$} & 0 & $2.33 \pm 0.18$ & - \\
\cline { 2 - 4 } & 1.00 & $3.28 \pm 0.17$ & 95 \\
\cline { 2 - 4 } & 2.00 & $4.27 \pm 0.18$ & 97 \\
\hline \multirow{3}{*}{$\mathrm{Mn}(\mu \mathrm{g} / \mathrm{g})$} & 0 & $0.13 \pm 0.03$ & - \\
\cline { 2 - 4 } & 0.50 & $0.60 \pm 0.02$ & 94 \\
\cline { 2 - 4 } & 1.00 & $1.09 \pm 0.03$ & 96 \\
\hline \multirow{2}{*}{$\mathrm{Zn}(\mu \mathrm{g} / \mathrm{g})$} & 0 & $0.158 \pm 0.002$ & - \\
\cline { 2 - 4 } & 0.10 & $0.255 \pm 0.008$ & 97 \\
\cline { 2 - 4 } & 0.20 & $0.356 \pm 0.010$ & 99 \\
\hline
\end{tabular}

Note: Values are the averages of three independent measurements.

\section{CONCLUSIONS}

Our study has shown that different parts of the Fagonia cretica accumulate diverse levels of macronutrients and heavy metals. In general, leaves of the Fagonia cretica have accumulated the highest concentration of various metals. This medicinal plant is rich in some minerals, especially $\mathrm{Ca}, \mathrm{K}$ and $\mathrm{Mg}$ which are essential for human health. Heavy metals like $\mathrm{Cu}, \mathrm{Fe}$ and $\mathrm{Zn}$ have been detected accurately and precisely both by AAS and ICP-OES. Keeping in view the significant role of various metals in combating a variety of human ailments and diseases, a periodical assessment of heavy metals in herbal plants before their use for traditional medicine and pharmaceutical purposes is recommended. 


\section{ACKNOWLEDGEMENTS}

The authors gratefully acknowledge Hakim Nasir-ul-Haque for extending help in identification of the plant and confirming the localized use of $F$. cretica for the treatment of various diseases including cancer. We also acknowledge the technical assistance of Tanveer Ahmad, Naveed

Sajid and Saeed Ahmad. The authors are thankful to Director Systems \& Services and Director General of PINSTECH for their administrative support and permission to publish this study.

\section{REFERENCES}

1. Hooker, J.D. Flora of British India, Reeve and Co.: London; 1882.

2. Tyler, V.E.; Brady, E.R.; Robbers, J.E. Pharmacognosy, 9th ed., Lea \& Febiger: Philadelphia; 1988.

3. Wang, X.; Zhuang, Z.; Sun, D.; Hong, J.X.; Wu, X.; Lee, F.S.; Yang, M.S.; Leung, H.W. At. Spectrom. 1999, 20, 86.

4. Chan, K. Chemosphere 2003, 52, 1361.

5. Lesniewicz, A.; Jaworska, K.; Zyrnicki, W. Food Chem. 2006, 99, 670.

6. Nielsen, F.H. J. Trace Elem. Exp. Med. 1998, 11, 251.

7. Berman, A.F. The Lancet 2000, 355, 134.

8. Yarnell, E.; Abascal, K. Altern. Complemen. Ther. 2003, 9, 299.

9. Saper, R.B.; Kales, S.N.; Paquin, J.; Burns, M.J.; Eisenberg, D.M.; Davis, R.B.; Phillips, R.S. JAMA 2004, 292, 2868.

10. Hussain, A.; Zia, M.; Mirza, B. Turk. J. Biol. 2007, 31, 19.

11. Ahmad, S.S. Pak. J. Bot. 2007, 39, 355.

12. Khare, C.P. Indian Medicinal Plants: An Illustrated Dictionary, Springer-Verlag: Berlin; 2007; p 259.

13. Prasad, S.; Kashyap, R.S.; Deopujari, J.Y.; Purohit, H.J.; Taori, G.M.; Daginawala, H.F. BMC Complemen. Altern. Med. 2007, 7, 36.

14. Basgel, S.; Erdemoglu, S.B. Sci. Tot. Environ. 2006, 359, 82.

15. Olowoyo, J.O.; Okedeyi, O.O.; Mkolo, N.M.; Lion, G.N.; Mdakane, S.T.R. South Afr. J. Bot. 2012, 78, 116.

16. Chuang, I.C.; Chen, K.S.; Huang, Y.L.; Lee, P.N.; Lin, T.H. Biol. Trace Elem. Res. 2000, $76,235$.

17. Gomez, M.R.; Cerutti, S.; Olsina, R.A.; Silva, M.F.; Martinez, L.D. J. Pharm. Biomed. Anal. 2004, 34, 569.

18. Flores, E.M.M.; Saidelles, A.P.F.; Mattos, J.P.C.; Muller, E.I.; Pereira, J.S.F.; Paniz, J.N.G.; Dressler, V.L. Int. J. Environ. Anal. Chem. 2009, 89, 129.

19. Zivkovic, J.; Razic, S.; Arsenijevic, J.; Maksimovic, Z. J. Serb. Chem. Soc. 2012, 77, 959.

20. Krachler, M.; Mohl, C.; Emons, H.; Shotyk, W. Spectrochim. Acta Part B: At. Spectrom. 2002, 57, 1277.

21. Butcher, D.J.; Sneddon, J. A Practical Guide to Graphite Furnace Atomic Absorption Spectrometry, Wiley: New York; 1998.

22. Resano, M.; Garcia-Ruiz, E.; Crespo, C.; Vanhaecke, F.; Belarra, M. A. J. Anal. At. Spcetrom. 2003, 18, 1477.

23. Dogo, S.; Razic, S.; Manojlovic, D.; Slavkovic, L. J. Serb. Chem. Soc. 2011, 76, 143.

24. Turan, M.; Kordali, S.; Zengin, H.; Dorsun, A.; Sezen, Y. Acta Agric. Scand., Section B Soil \& Plant Sci. 2003, 53, 129.

25. Ekinci, N.; Ekinci, R.; Polat, R.; Budak, G. J. Radioanal. Nucl. Chem. 2004, 260, 127. 
Macronutrients and heavy metals in Fagonia cretica of Pakistan by atomic spectroscopy 185

26. Shill, M.E.G.; Yong, V.R. Modern Nutrition in Health and Diseases in Nutrition, Nieman D.C.; Buthepodorth D.E.; Nieman, C.N. (Eds.), WMC Brown Publisher: USA; 1988.

27. Okaka, J.C.; Enoch, N.T.; Akobundu, A.; Okaka, N.C. Human Nutrition: An Integrated Approach, 2nd ed., Academic Publisher: Enugu (Nigeria); 2001.

28. Friday, E.T.; James, O.; Olusegun, O.; Gabriel, A. Int. J. Plant Physiol. Biochem. 2011, 3, 95.

29. Jauncey, K. Nutritional Requirement in Tilapias: Biology and Exploitation, Beveridge, M.C.M.; McAndrew, B.J. (Eds.), Kluwer Academic Publisher: London; 2000.

30. Anderson, R.A.; Polansky, M.M.; Bryden, N.K.; Bhathena, S.J.; Canary, J.J. Metabolism 1987, 36, 351.

31. Vonk, W.I.M.; Wejmenga, C.; van de Sluis, B. Am. J. Clin. Nutr. 2008, 88, 840.

32. Yanik, M.; Kocyigit, A.; Tutkum, H.; Vural, H.; Herken, H. Biol. Trace Elem. Res. 2004, 98, 109.

33. Martin Jr, D.W.; Mayers, P.A.; Rodwell, V.W.; Granner, D.K. Harper's Review of Biochemistry, 20th ed., Lange Medical Publications: California; 1985.

34. Geleijnse, J.M.; Witteman, J.C.M.; Bak, A.A.A.; den Breeijen, J.H.; Grobbee, D.E. British Med. J. 1994, 309, 436.

35. Ammann, P. Bone 2006, 38, 15.

36. Obiajunwa, E.L.; Adebiyi, F.M.; Omode, P.E. Pak. J. Nutr. 2005, 4, 393.

37. Yamashita, C.I.; Saiki, M.; Vasconcellos, M.B.A.; Sertie, J.A.A. Appl. Rad. Isotopes 2005, 63,841 .

38. Steeves, M.; Abdallah, H.Y.; Venkataramanan, R.; Burckart, G.J.; Ptachcinski, R.J.; AbuElmagd, K.; Jain, A.K.; Fung, F.; Todo, S.; Starzl, T.E. J. Pharmacy Pharm. 1991, 43, 574. 